\title{
Glycyrrhizic acid activates chicken macrophages and enhances their Salmonella-killing capacity in vitro ${ }^{* \#}$
}

\author{
Bai-kui WANG ${ }^{\S 1}$, Yu-long MAO ${ }^{\S 1}, \mathrm{Li} \mathrm{GONG}^{1}$, Xin XU ${ }^{1}$, Shou-qun JIANG ${ }^{2}$, Yi-bing WANG ${ }^{1}$, Wei-fen $\mathrm{LI}^{\dagger}+1$ \\ ${ }^{1}$ Key Laboratory of Animal Molecular Nutrition of Education of Ministry, Key Laboratory of Animal Feed and Nutrition of \\ Zhejiang Province, College of Animal Sciences, Zhejiang University, Hangzhou 310058, China \\ ${ }^{2}$ Institute of Animal Science, Guangdong Academy of Agricultural Sciences, State Key Laboratory of Livestock and Poultry Breeding, \\ Key Laboratory of Animal Nutrition and Feed Science in South China, Ministry of Agriculture, Guangdong Public Laboratory of \\ Animal Breeding and Nutrition, Guangdong Key Laboratory of Animal Breeding and Nutrition, Guangzhou 510640, China \\ †E-mail: wfli@zju.edu.cn
}

Received Oct. 8, 2017; Revision accepted Dec. 28, 2017; Crosschecked Sept. 10, 2018

\begin{abstract}
Objective: Salmonella enterica remains a major cause of food-borne disease in humans, and Salmonella Typhimurium (ST) contamination of poultry products is a worldwide problem. Since macrophages play an essential role in controlling Salmonella infection, the aim of this study was to evaluate the effect of glycyrrhizic acid (GA) on immune function of chicken HD11 macrophages. Methods: Chicken HD11 macrophages were treated with GA $(0,12.5$, $25,50,100,200,400$, or $800 \mu \mathrm{g} / \mathrm{ml}$ ) and lipopolysaccharide (LPS, $500 \mathrm{ng} / \mathrm{ml}$ ) for 3, 6, 12, 24, or $48 \mathrm{~h}$. Evaluated responses included phagocytosis, bacteria-killing, gene expression of cell surface molecules (cluster of differentiation 40 (CD40), CD80, CD83, and CD197) and antimicrobial effectors (inducible nitric oxide synthase (iNOS), NADPH oxidase-1 (NOX-1), interferon- $\gamma$ (IFN- $y$ ), LPS-induced tumor necrosis factor (TNF)- $\alpha$ factor (LITAF), interleukin-6 (IL-6), and $I L-10)$, and production of nitric oxide (NO) and hydrogen peroxide $\left(\mathrm{H}_{2} \mathrm{O}_{2}\right)$. Results: GA increased the internalization of both fluorescein isothiocyanate (FITC)-dextran and ST by HD11 cells and markedly decreased the intracellular survival of ST. We found that the messenger RNA (mRNA) expression of cell surface molecules (CD40, CD80, CD83, and CD197) and cytokines (IFN- $y, I L-6$, and IL-10) of HD11 cells was up-regulated following GA exposure. The expression of $i N O S$ and NOX-1 was induced by GA and thereby the productions of $\mathrm{NO}$ and $\mathrm{H}_{2} \mathrm{O}_{2}$ in $\mathrm{HD} 11$ cells were enhanced. Notably, it was verified that nuclear factor-KB (NF-KB) and c-Jun N-terminal kinase (JNK) pathways were responsible for GA-induced synthesis of NO and IFN- $\gamma$ gene expression. Conclusions: Taken together, these results suggested that GA exhibits a potent immune regulatory effect to activate chicken macrophages and enhances Salmonella-killing capacity.
\end{abstract}

Key words: Glycyrrhizic acid; Chicken macrophage; Macrophage activation; Salmonella Typhimurium; Nuclear factor KB (NF-KB); c-Jun N-terminal kinase (JNK) https://doi.org/10.1631/jzus.B1700506

CLC number: S816.3

\footnotetext{
${ }^{\ddagger}$ Corresponding author

$\S$ The two authors contributed equally to this work

* Project supported by the National Natural Science Foundation of China (No. 31472128)

\# Electronic supplementary materials: The online version of this article (https://doi.org/10.1631/jzus.B1700506) contains supplementary materials, which are available to authorized users

(ii) ORCID: Wei-fen LI, https://orcid.org/0000-0001-8159-9876

(C) Zhejiang University and Springer-Verlag GmbH Germany, part of Springer Nature 2018
}

\section{Introduction}

Salmonella is one of the leading causes of foodborne disease worldwide (Scallan et al., 2015). Outbreaks and sporadic cases have indicated that food vehicles such as poultry and poultry by-products are among the most common sources of Salmonella infections (Revolledo et al., 2009). In chickens, Salmonella Typhimurium (ST) and Salmonella Enteritidis 
(SE) are major food-borne Salmonella serovars which can colonize or invade the gastrointestinal tract and thus contaminate meat and eggs and cause food poisoning (He et al., 2012). With the restrictions on the use of antibiotics, alternative approaches such as dietary interventions are being evaluated to improve animal health and control Salmonella infection. Notable among the interventions is the use of plant extracts in animal feed as they are considered to be "natural" additives and have been shown to be effective immune modulators in response to pathogen infections (Pugh et al., 2005).

Macrophages are key components of the immune system and provide protection against a wide variety of infections. Stimulated macrophages are not only phagocytic cells which detect, phagocytize, and eliminate infectious agents but also serve as antigenpresenting cells for $\mathrm{B}$ and $\mathrm{T}$ lymphocytes and participate in the stimulation of the adaptive immune system (Setta et al., 2012). However, as a facultative intracellular pathogen, Salmonella is able to produce effector proteins which manipulate macrophages to delay the phagolysosomal maturation and thus avoid exposure to lysosomal contents (Haraga et al., 2008). The ability of Salmonella to survive and multiply within chicken macrophages is crucial for Salmonella virulence and pathogenesis (Barrow et al., 1994). To control intracellular Salmonella, macrophages are activated to produce several antimicrobial substances such as nitric oxide (NO) and hydrogen peroxide $\left(\mathrm{H}_{2} \mathrm{O}_{2}\right)$ and secrete a group of cytokines and chemokines such as interferon- $\gamma$ (IFN- $\gamma$ ) and interleukin-12 (IL-12) (Ibuki et al., 2011). Previous studies demonstrated that mitogen-activated protein kinase (MAPK) and nuclear factor- $\mathrm{\kappa B}(\mathrm{NF}-\mathrm{\kappa B})$ pathways are involved in macrophage activation and play a critical role in pro-inflammatory effector production and autophagy formation (Mosser and Edwards, 2008; He et al., 2012). These have been shown to be important in controlling intracellular pathogens.

The roots and rhizomes of the Glycyrrhiza species (licorice) have been widely used as natural sweeteners and herbal medicines. Glycyrrhizic acid (GA), a major biologically active constituent of licorice root, consists of one molecule of 18-glycyrrhetinic acid and two molecules of glucuronic acid (Matsui et al., 2004). So far, GA has been reported to have anti-viral, anti-cancer, anti-apoptotic, and anti-inflammatory ac- tivity (Honda et al., 2012; Wang et al., 2017). Previous studies indicated that GA may act as a potent anti-infectious agent in the process of pathogen invasion by targeting particular immune cells like macrophages and dendritic cells (Bhattacharjee et al., 2012; Hua et al., 2012). In a mouse model, GA treatment caused an enhanced production of NO along with inhibition of intracellular survival of Leishmania donovani in macrophages and decreased hepatic and splenic parasite burden in vivo (Bhattacharjee et al., 2012). GA could also increase the productions of IL-12 and IFN- $\beta$ in macrophages and exhibits a curative effect on several virus infections such as severe acute respiratory syndrome-coronavirus (SARS-CV), human immunodeficiency virus type 1 (HIV-1), and highly pathogenic avian influenza A (H5N1) (Dai et al., 2001; Cinatl et al., 2003; Michaelis et al., 2010). However, most of these studies are focused on mammals, and there is no report on the effect of GA on immune function in chickens. In the present study, we investigated the effects of GA on phagocytic and bacteria-killing activity against ST of the chicken macrophage. Additionally, the expression of cell surface molecules and antimicrobial genes, production of antimicrobial effectors, and its possible mechanisms were analyzed.

\section{Materials and methods}

\subsection{Cells and glycyrrhizic acid treatment}

The chicken macrophage cell line (HD11) was generously provided by Dr. Shou-qun JIANG (Guangdong Academy of Agricultural Sciences, Guangzhou, China). Cells were grown in Roswell Park Memorial Institute (RPMI)-1640 medium (Gibco, USA) supplemented with $10 \%(\mathrm{v} / \mathrm{v})$ chicken serum (Gibco, USA), $100 \mu \mathrm{g} / \mathrm{ml}$ streptomycin and $100 \mathrm{U} / \mathrm{ml}$ penicillin (Sigma-Aldrich, St. Louis, MO, USA), nonessential amino acids $(1 \times)$, sodium pyruvate $(1 \mathrm{mmol} / \mathrm{L})$, L-glutamine $(2 \mathrm{mmol} / \mathrm{L})$ and 2-mercaptoethanol $\left(5 \times 10^{-5} \mathrm{~mol} / \mathrm{L}\right)$ at $41^{\circ} \mathrm{C}$ in a $5 \%(\mathrm{v} / \mathrm{v})$ humidified $\mathrm{CO}_{2}$ incubator.

GA was purchased from Sigma-Aldrich (purity $\geq 95.0 \%$ (neutralization titration (NT)), St. Louis, MO, USA) and suspended in sterile phosphate-buffered saline (PBS). There was no detectable endotoxin $(<0.10$ endotoxin units $/ \mathrm{ml})$ in the GA samples, as 
determined by Endospecy method (Seikagakukougyo, Osaka, Japan). Stocks of GA were frozen in aliquots of $100 \mu \mathrm{l}$ at $10 \mathrm{mg} / \mathrm{ml}$. The Stock was diluted to the appropriate concentrations in the media indicated by the experiment.

\subsection{Cell viability assay}

HD11 cells were seeded at $1 \times 10^{4} \mathrm{ml}^{-1}$ in 96-well microplates (Corning, USA) and treated with PBS or GA $(12.5,25,50,100,200,400$, and $800 \mu \mathrm{g} / \mathrm{ml})$ for $48 \mathrm{~h}$. MTT (3-(4,5-dimethylthiazol-2-yl)-2,5diphenyltetrazolium bromide; Sigma-Aldrich, St. Louis, MO, USA) assay (Mao et al., 2015) was then used to investigate the relative cell viabilities.

\subsection{Phagocytosis assay}

HD11 cells seeded into 12-well plates (Corning, $1 \times 10^{6}$ cells $\left./ \mathrm{ml}\right)$ were pretreated with PBS or GA $(25$, 50 , and $100 \mu \mathrm{g} / \mathrm{ml}$ ) for $12 \mathrm{~h}$, and then incubated with fluorescein isothiocyanate (FITC)-dextran (1 mg/ml, molecular weight 40000; Sigma-Aldrich, St. Louis, MO, USA) at $41^{\circ} \mathrm{C}$ for $1 \mathrm{~h}$. After incubation, the cells were washed with PBS to remove excess dextran. The percentage and mean fluorescence intensity (MFI) of intracellular FITC-dextran were determined using FACScalibur flow cytometer (Becton-Dickinson, USA).

\subsection{Salmonella-killing analysis}

The effect of GA on the Salmonella-killing capacity of chicken macrophages was measured by a viable count method, as described previously (Ibuki et al., 2011). Briefly, HD11 cells seeded into 24-well plates (Corning, $2 \times 10^{5}$ cells $/ \mathrm{ml}$ ) were preincubated with GA $(100 \mu \mathrm{g} / \mathrm{ml})$ for $12 \mathrm{~h}$. The cells were then washed and incubated with ST (strain CMCC-50115, $2 \times 10^{7}$ colony forming units (CFU)/well) for $1 \mathrm{~h}$ at $41{ }^{\circ} \mathrm{C}$ to allow bacterial adhesion and colonization. Thereafter, cells were washed twice with PBS and incubated in RPMI-1640 containing gentamicin $(25 \mu \mathrm{g} / \mathrm{ml})$ for 0,12 , and $24 \mathrm{~h}$. Finally, cell lysates from HD11 cells containing intracellular bacteria were serially diluted with PBS and spread onto Salmonella-Shigella (SS) agar plates to determine bacterial viability.

\section{5 qPCR analysis}

HD11 cells were seeded into 12 -well plates $(1 \times$ $10^{6}$ cells $\left./ \mathrm{ml}\right)$ and pretreated with PBS, GA $(100 \mu \mathrm{g} / \mathrm{ml})$, or lipopolysaccharide (LPS, $500 \mathrm{ng} / \mathrm{ml}$ ) for $0,3,6$, and $12 \mathrm{~h}$, and then washed by PBS three times to collect the cell pellets. The co-cultured cell pellets were re-suspended in RNAiso Plus (TaKaRa, Dalian, China) and then placed in liquid nitrogen. All samples were frozen and kept at $-80{ }^{\circ} \mathrm{C}$ for no more than one week for further RNA isolation. Total RNA was isolated from the treated cells using RNAiso Plus (TaKaRa, Dalian, China) according the manufacturer's recommendations. Qualitative and quantitative analyses of RNA were determined by the ratio of absorbance readings at 260 and $280 \mathrm{~nm}\left(A_{260} / A_{280}\right)$ using a NanoDrop spectrophotometer (Thermo Scientific, Wilmington, DE, USA) and agarose gel electrophoresis (Sangon Biotech, Shanghai, China). One microgram of total RNA from each sample was reversetranscripted into complementary DNA (cDNA) using PrimeScript II 1st Strand cDNA Synthesis Kit (TaKaRa, Dalian, China) following the manufacturer's recommendations. The cDNA samples were then tested for gene expression by reverse transcriptionquantitative polymerase chain reaction (RT-qPCR) performed using SYBR Green PCR Master Mix (Applied Biosystems, Carlsbad, CA, USA) on a StepOne Plus real-time PCR system (Applied Biosystems, Carlsbad, CA, USA). All samples were denatured for $30 \mathrm{~s}$ at $95^{\circ} \mathrm{C}$, followed by 40 cycles of PCR amplification ( $5 \mathrm{~s}$ denaturation at $95{ }^{\circ} \mathrm{C}, 34 \mathrm{~s}$ annealing/ extension at $60{ }^{\circ} \mathrm{C}$ ), and then a final melting curve analysis to monitor purity of the PCR product. Each sample was run in triplicate. Primer sequences for chicken macrophage genes were designed and selected by Primer 6.0 and Oligo 7.0 software and the sequences are listed in Table 1. $\beta$-actin was used as reference gene and relative quantification was calculated using the $2^{-\Delta \Delta C_{\mathrm{q}}}$ method (Bustin et al., 2009), where $C_{\mathrm{q}}$ is quantification cycle, $\Delta C_{\mathrm{q}}$ is $C_{\mathrm{q} \text {, target }}{ }^{-}$

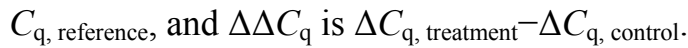

\subsection{Nitrite generation assay}

HD11 cells were seeded into 12-well plates $\left(1 \times 10^{6}\right.$ cells $\left./ \mathrm{ml}\right)$ and pretreated with PBS, GA $(25,50$, and $100 \mu \mathrm{g} / \mathrm{ml})$ or LPS $(500 \mathrm{ng} / \mathrm{ml})$ for $48 \mathrm{~h}$. Then NO production was estimated by the Greiss method (Ding et al., 1988). Briefly, equal volumes $(100 \mu \mathrm{l})$ of cellfree supernatant and Greiss reagent $(0.01 \mathrm{~g} / \mathrm{ml} \mathrm{sul-}$ fanilamide, $1 \mathrm{~g} / \mathrm{L}$ naphthylenediamide, and 5\% (v/v) phosphoric acid; Sigma-Aldrich, St. Louis, MO, USA) were mixed for $10 \mathrm{~min}$ at room temperature. The 
Table 1 List of real-time PCR primers

\begin{tabular}{|c|c|c|c|}
\hline Gene name & Primer $\left(5^{\prime} \rightarrow 3^{\prime}\right)$ & Product (bp) & Accession number \\
\hline \multirow[t]{2}{*}{ CD40 } & F: GGCACCTTCTCCAATGTATCTTC & 96 & NM_204665 \\
\hline & R: GTTCGTCCCTTTCACCTTCAC & & \\
\hline \multirow[t]{2}{*}{$C D 80$} & F: CAGCAAGCCGAACATAGAAAGA & 270 & NM_001079739 \\
\hline & R: AGCAAACTGGTGGACCTGAGA & & \\
\hline \multirow[t]{2}{*}{$C D 83$} & F: GCTGACTTGCCTCGGGATT & 272 & XM_418929 \\
\hline & R: TCACTCCGCTATCCGTCTCA & & \\
\hline \multirow[t]{2}{*}{ CD197 } & F: GACGACTATGACGCCAACAC & 211 & NM_001198752 \\
\hline & R: CCAGGTTCAGCAAGTAGATGTC & & \\
\hline \multirow[t]{2}{*}{$i N O S$} & F: CCACCAGGAGATGTTGAACTATG & 160 & NM_204961 \\
\hline & R: CAGGAGTAATGACGCCAAGAG & & \\
\hline \multirow[t]{2}{*}{$N O X-1$} & F: CTGGACGGAGCACATCATTG & 281 & NM_001101830 \\
\hline & R: AGGCAAGCAGGTCATTGAAC & & \\
\hline \multirow[t]{2}{*}{$I F N-\gamma$} & F: ACAAGTCAAAGCCGCACATC & 83 & NM_205149 \\
\hline & R: CACCTTCTTCACGCCATCAG & & \\
\hline \multirow[t]{2}{*}{ LITAF } & F: GGACAGCCTATGCCAACAAG & 81 & NM_204267 \\
\hline & R: GCGGTCATAGAACAGCACTAC & & \\
\hline \multirow[t]{2}{*}{$I L-6$} & F: CTCCTCGCCAATCTGAAGTC & 99 & NM_204628 \\
\hline & R: CCTCACGGTCTTCTCCATAAAC & & \\
\hline \multirow[t]{2}{*}{$I L-10$} & F: ACCAGTCATCAGCAGAGCAT & 222 & NM_001004414 \\
\hline & R: CCTCCTCATCAGCAGGTACTC & & \\
\hline \multirow[t]{2}{*}{$\beta$-actin } & F: ACCCTGAAGTACCCCATTGAAC & 107 & NM_205518 \\
\hline & R: TGCTCCTCACGGGCTACTCT & & \\
\hline
\end{tabular}

F: forward; R: reverse

absorbency was then read at $550 \mathrm{~nm}$ by a SpectraMax M5 (Molecular Devices, Sunnyvale, CA, USA) and the actual NO concentration was calculated using a standard curve with serial dilutions of sodium nitrite.

\section{$2.7 \mathrm{H}_{2} \mathrm{O}_{2}$ generation assay}

$\mathrm{H}_{2} \mathrm{O}_{2}$ production was measured using a hydrogen peroxide assay kit (Beyotime Biotech, Shanghai, China). Briefly, cell lysates from cultured cells treated as above for $12 \mathrm{~h}$ were mixed with double volumes of test solutions at room temperature for $20 \mathrm{~min}$. The absorbance at $560 \mathrm{~nm}$ was then measured using a SpectraMax M5 and the actual concentration was calculated using a standard curve with serial dilutions of $\mathrm{H}_{2} \mathrm{O}_{2}$.

\subsection{Neutralization experiments}

HD1 1 cells $\left(1 \times 10^{6}\right.$ cells $\left./ \mathrm{ml}\right)$ were pretreated with NF-kB inhibitor (BAY 11-7082, $20 \mu \mathrm{mol} / \mathrm{L}$ ), c-Jun N-terminal kinase (JNK) inhibitor (SP600125, $20 \mu \mathrm{mol} / \mathrm{L}$ ), p38 inhibitor (SB203580, $20 \mu \mathrm{mol} / \mathrm{L}$ ), or extracellular signal-regulated kinase $1 / 2$ (ERK1/2) inhibitor (U0126, $20 \mu \mathrm{mol} / \mathrm{L}$ ) (Beyotime Biotech,
Shanghai, China) for $30 \mathrm{~min}$, and subsequently stimulated with GA $(100 \mu \mathrm{g} / \mathrm{ml})$ for 48 or $6 \mathrm{~h}$. Supernatants and cell lysates from cultured cells were analyzed for the production of NO and $I F N-\gamma$ gene expression according to the above methods.

\subsection{Statistical analysis}

Differences were analyzed by two-tailed Student's $t$-test using SPSS 16.0 (SPSS Inc., Chicago, IL, USA) for Windows and results were expressed as mean \pm standard deviation (SD) of at least three independent experiments. All statistical analyses were performed using Origin 8.0 (Origin Lab, MA, USA). $P<0.05$ was considered statistically significant.

\section{Results}

\subsection{Cytotoxicity analysis of glycyrrhizic acid on chicken macrophages}

No obvious cytotoxicity was observed when chicken macrophage HD11 cells were incubated with GA $(12.5,25,50,100,200$, and $400 \mu \mathrm{g} / \mathrm{ml})$ for $48 \mathrm{~h}$ 
$(P>0.05)$. In contrast, cells treated with $800 \mu \mathrm{g} / \mathrm{ml}$ GA exhibited a significantly lower survival rate under given experimental conditions $(85.22 \%$, $P<0.05$; Fig. 1).

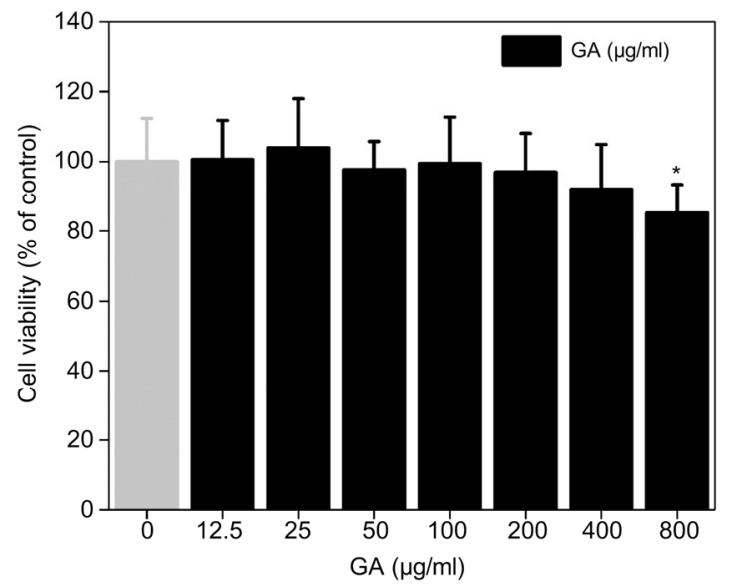

Fig. 1 Cytotoxicity analysis of glycyrrhizic acid (GA) on chicken macrophages

HD11 cells were incubated with PBS or GA $(12.5,25,50$, $100,200,400$, and $800 \mu \mathrm{g} / \mathrm{ml}$ ) for $48 \mathrm{~h}$ and cell viability was determined by the MTT method. Results are presented as mean \pm SD of eight samples. ${ }^{*} P<0.05$ vs. control (Student's $t$-test)

\subsection{Effects of glycyrrhizic acid on phagocytosis and Salmonella-killing activity of chicken macrophages}

GA dose-dependently enhanced the uptake of FITC-dextran by HD11 cells and a marked increase of all MFIs and marker 1 (M1) of FITC-dextran was observed in cultured cells pretreated with $100 \mu \mathrm{g} / \mathrm{ml}$ GA when compared to the control group $(P<0.05$; Fig. 2a). Therefore, $100 \mu \mathrm{g} / \mathrm{ml} \mathrm{GA}$ was used for the following experiments.

GA $(100 \mu \mathrm{g} / \mathrm{ml})$ significantly enhanced the uptake of intracellular bacteria ST in cultured cells compared to the control group $(P<0.05$; Fig. $2 \mathrm{~b}, 0 \mathrm{~h})$. The survival rate of ST in GA-pretreated cells decreased by more than two times at $24 \mathrm{~h}$ post infection as compared to uninfected cells $(P<0.01$; Fig. $2 \mathrm{~b}, 24 \mathrm{~h})$ In addition, we also investigated the antibacterial activity of GA against ST in vitro. However, it was found that GA affected neither the growth and proliferation nor the expression of virulence genes (e.g. $\operatorname{ssr} B, \operatorname{sip} B$, hilA, invA, and $\operatorname{sop} D)$ of ST $(P>0.05$; Figs. S1 and S2, Table S1).
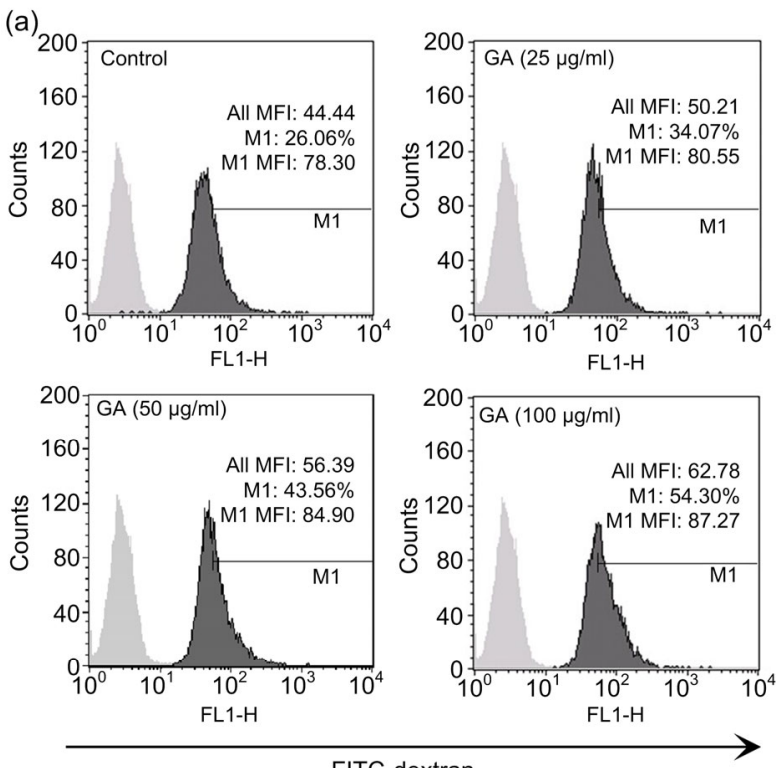

(b)

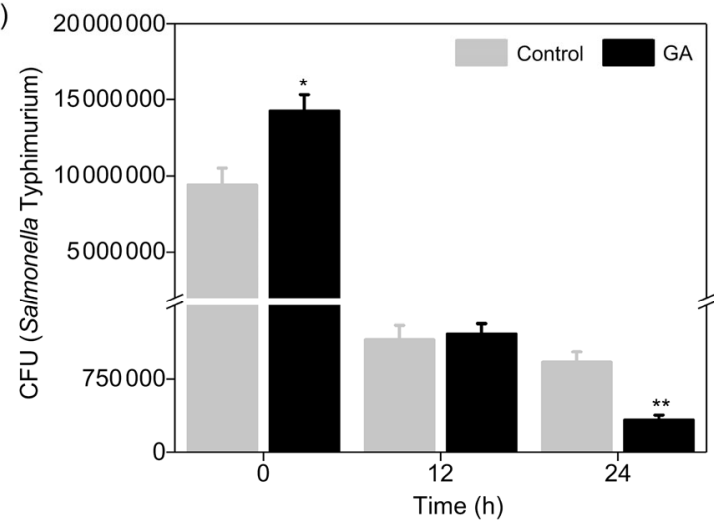

Fig. 2 Effects of glycyrrhizic acid (GA) on the phagocytosis and Salmonella-killing capacity of chicken macrophages

(a) HD11 cells were pretreated with GA $(25,50,100 \mu \mathrm{g} / \mathrm{ml})$ for $12 \mathrm{~h}$, and then incubated with FITC-dextran $(1 \mathrm{mg} / \mathrm{ml})$ at $41{ }^{\circ} \mathrm{C}$ for $1 \mathrm{~h}$. The intracellular FITC-dextran was measured by fluorescence-activated cell sorting (FACS). Marker 1 (M1): mean fluorescence intensity (MFI) $>50$. (b) HD11 cells were pretreated with GA $(100 \mu \mathrm{g} / \mathrm{ml})$ for $12 \mathrm{~h}$, and then infected with ST $\left(2 \times 10^{7} \mathrm{CFU} /\right.$ well $)$ for $1 \mathrm{~h}$. The cells were washed and incubated in RPMI-1640 medium with gentamicin $(25 \mu \mathrm{g} / \mathrm{ml})$ for 12 and $24 \mathrm{~h}$, and then these cells were lysed, diluted, and plated on SalmonellaShigella (SS) agar plates for colony enumeration. Data are expressed as mean \pm SD for three independent experiments. ${ }^{*} P<0.05,{ }^{* *} P<0.01$, vs. control (Student's $t$-test)

3.3 Effects of glycyrrhizic acid on activation and antimicrobial factor gene expression of chicken macrophages

As shown in Fig. 3, GA significantly upregulated the messenger RNA (mRNA) expression of 
cluster of differentiation 40 (CD40), CD80, CD83 (6 and $12 \mathrm{~h}$ ), and $C D 197$ ( 3 and $6 \mathrm{~h})(P<0.05)$. GA enhanced the expression of both inducible nitric oxide synthase (iNOS) and NADPH oxidase-1 (NOX-1) (Figs. $4 \mathrm{a}$ and $4 \mathrm{~b}$ ) and thereby increased the productions of $\mathrm{NO}$ and $\mathrm{H}_{2} \mathrm{O}_{2}$ (Figs. $4 \mathrm{c}$ and $\left.4 \mathrm{~d}\right)(P<0.05)$. Furthermore, the mRNA expression of immuneassociated cytokines, such as $I F N-\gamma$, LPS-induced tumor necrosis factor (TNF)- $\alpha$ factor $(L I T A F), I L-6$, and $I L-10$, was observed to be up-regulated in HD11 cells on GA exposure (Fig. 5).

\subsection{Effects of glycyrrhizic acid on the signaling pathways of chicken macrophages}

As demonstrated in Fig. 6, BAY 11-7082 (NF-KB inhibitor) and SP600125 (JNK inhibitor), but not SB203580 (p38 MAPK inhibitor), significantly blocked GA-mediated induction of $\mathrm{NO}$ and $I F N-\gamma$ $(P<0.05)$, whereas being pre-stimulated with U0126 (ERK1/2 inhibitor) resulted in unanticipated increase in NO level and $I F N-\gamma$ expression $(P<0.05)$.
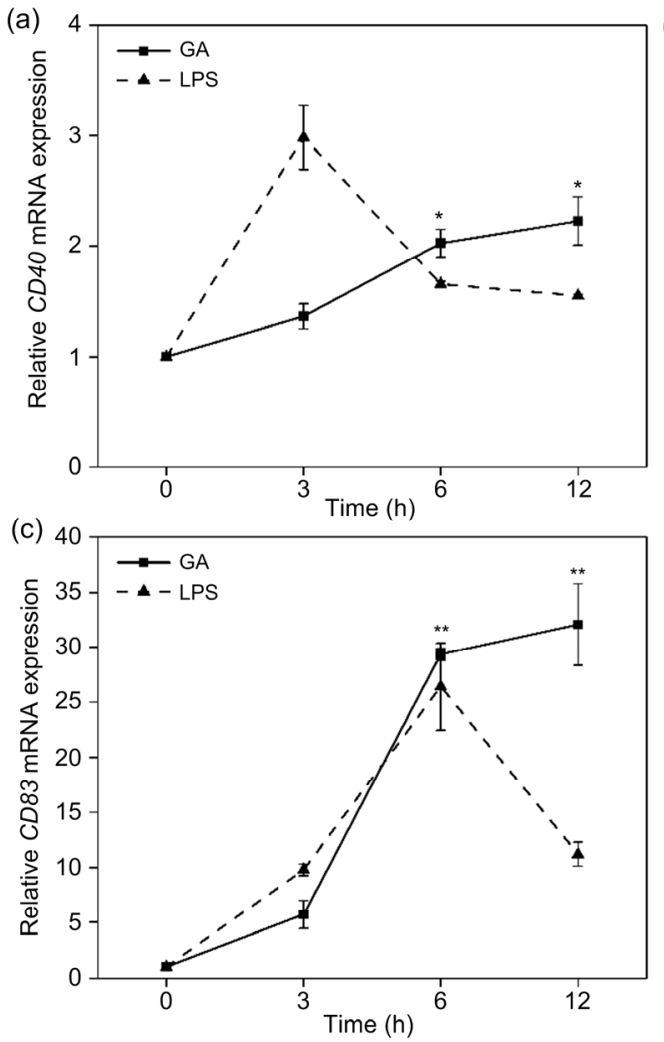

\section{Discussion}

Although the mechanisms against Salmonella infection are not fully understood, it is known that macrophages play a critical role in the initial recognition and control of Salmonella infections (Braukmann et al., 2015). Previous reports have shown that GA could provide protection against several intracellular pathogens in mammals through enhancing macrophage functions (Dai et al., 2001; Bhattacharjee et al., 2012). In the present study, the results found that GA, with a safe range of dose $(\leq 400 \mu \mathrm{g} / \mathrm{ml})$, could activate chicken macrophages and enhance the cells' phagocytic capacity and ability to clear intracellular ST, which has previously shown to be easily able to survive within chicken macrophages and transcribe high rates of Salmonella pathogenicity island 2 (SPI-2) genes (Braukmann et al., 2015).

The results verified that GA up-regulated the gene expression of $C D 40, C D 80, C D 83$, and CD197. CD40, CD80, and CD197 are characteristic costimulatory
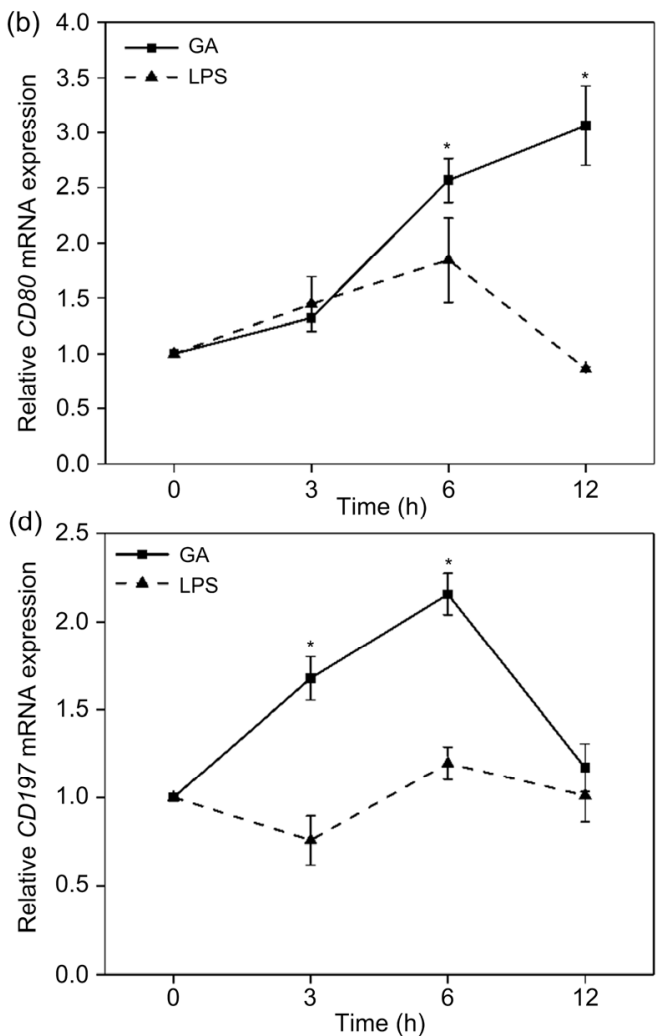

Fig. 3 Effects of glycyrrhizic acid (GA) on the expression of cell surface molecules in chicken macrophages HD1 1 cells were incubated with PBS, GA $(100 \mu \mathrm{g} / \mathrm{ml})$, or lipopolysaccharide (LPS, $500 \mathrm{ng} / \mathrm{ml})$ for 3, 6, and $12 \mathrm{~h}$. Total RNA was isolated and the gene expression of $C D 40$ (a), CD80 (b), CD83 (c), and CD197 (d) was analyzed by real-time $\mathrm{PCR}$. Results are expressed as fold change relative to untreated cells (at time $0 \mathrm{~h}$ ). Data are expressed as mean $\pm \mathrm{SD}$ for three independent experiments. ${ }^{*} P<0.05,{ }^{* *} P<0.01$, vs. $0 \mathrm{~h}$ (Student's $t$-test) 

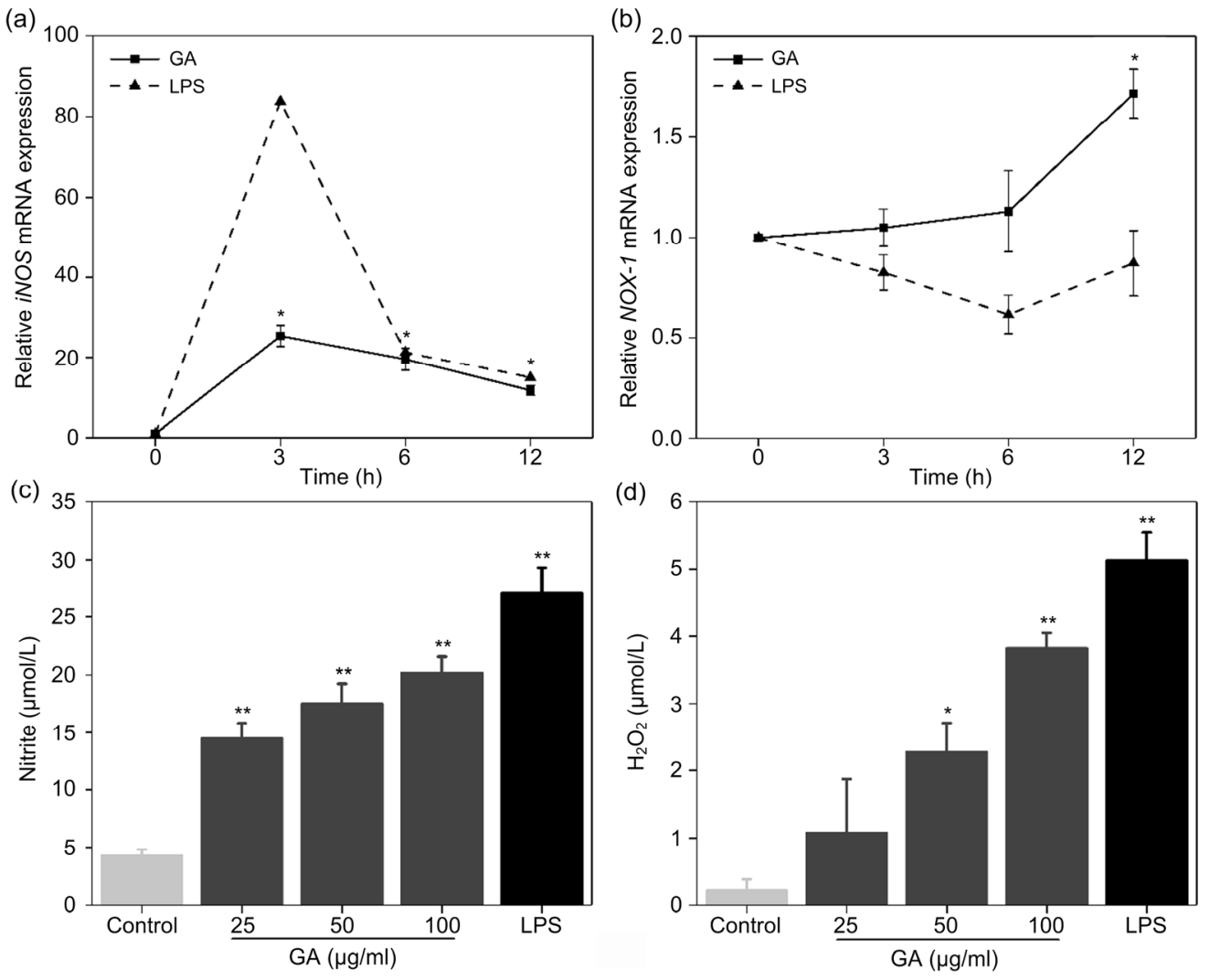

Fig. 4 Effects of glycyrrhizic acid (GA) on the productions of nitrite and hydrogen peroxide in chicken macrophages (a, b) HD11 cells were incubated with PBS, GA $(100 \mu \mathrm{g} / \mathrm{ml})$, or lipopolysaccharide (LPS, $500 \mathrm{ng} / \mathrm{ml})$ for 3, 6, and $12 \mathrm{~h}$. Then total RNA was isolated and the expression of $i N O S$ (a) and NOX-1 (b) was analyzed by real-time PCR. (c, d) HD11 cells were incubated with PBS, GA $(25,50$, and $100 \mu \mathrm{g} / \mathrm{ml})$, or LPS $(500 \mathrm{ng} / \mathrm{ml})$ for $48 \mathrm{~h}(\mathrm{NO})$ or $12 \mathrm{~h}\left(\mathrm{H}_{2} \mathrm{O}_{2}\right)$. Culture supernatants and cell lysates were collected and the productions of $\mathrm{NO}$ (c) and $\mathrm{H}_{2} \mathrm{O}_{2}(\mathrm{~d})$ were analyzed. Data are expressed as mean $\pm \mathrm{SD}$ for three independent experiments. ${ }^{*} P<0.05,{ }^{* *} P<0.01 \mathrm{vs} .0 \mathrm{~h}(\mathrm{a}, \mathrm{b})$ or control (c, d) (Student's $t$-test)

molecules or markers for activated macrophages and play an important role in the inflammatory response to pathogen infection (Nolan et al., 2008; Brown et al., 2009). CD83 is essentially expressed on the surface of mature dendritic cells and participates in the interaction between antigen-presenting cells and $\mathrm{T}$ lymphocytes (Tang et al., 2005; Rimaniol et al., 2007). This induction of CD83 as well as costimulatory molecules (e.g. CD80) on macrophages suggested that GA could enhance the ability of macrophages to favor $\mathrm{T}$ lymphocyte activation. These results not only confirm that GA activates an innate immune response in chicken macrophages to eliminate intracellular ST, but also suggest that GA may contribute to the activation of adaptive immune response in vivo.
iNOS is generally associated with the immune system and can generate high levels of $\mathrm{NO}$, which exhibits potent antivirus and antibacterial effects via several mechanisms such as mutation of DNA and inhibition of protein synthesis (Bogdan, 2001). NOX-1 is a primary NOX in macrophages. It produces superoxide from oxygen and subsequently leads to the generation of other toxic reactive oxygen intermediates, such as $\mathrm{H}_{2} \mathrm{O}_{2}$ (Rosenberger and Finlay, 2002). Previous reports have shown that both iNOS and NOX activity impaired Salmonella replication (Rosenberger and Finlay, 2002), and mice deficient in iNOS and NOX were unable to control ST infection (Mastroeni et al., 2000). In the present study, GA could significantly up-regulate $i N O S$ and $N O X-1$ 

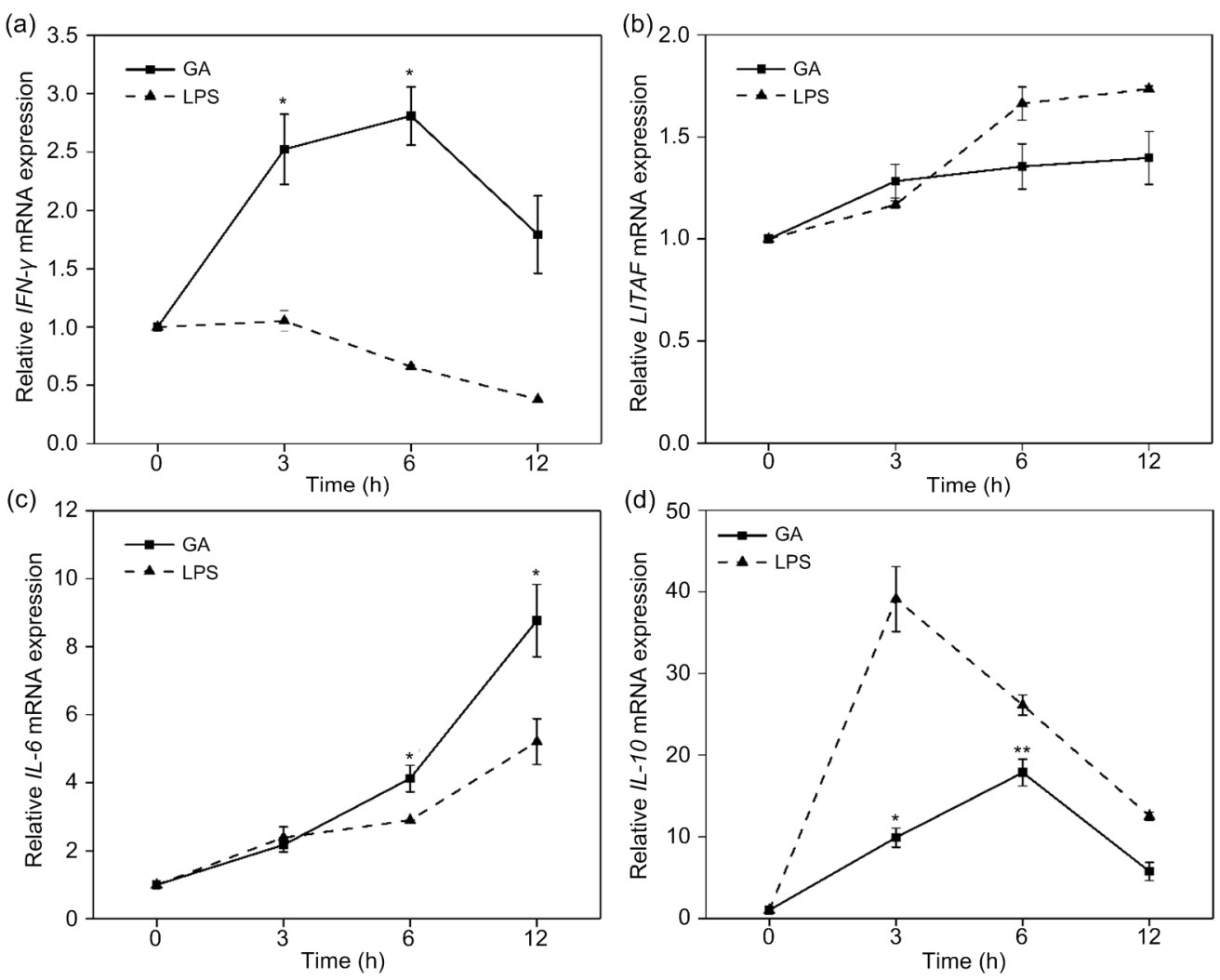

Fig. 5 Effects of glycyrrhizic acid (GA) on the expression of immune-associated cytokines in chicken macrophages HD11 cells were incubated with PBS, GA $(100 \mu \mathrm{g} / \mathrm{ml})$, or lipopolysaccharide (LPS, $500 \mathrm{ng} / \mathrm{ml})$ for 3, 6, and $12 \mathrm{~h}$. Then total RNA was isolated and the gene expression of $I F N-\gamma$ (a), LITAF (b), IL-6 (c), and $I L-10$ (d) was analyzed by real-time PCR. Results are expressed as mean $\pm \mathrm{SD}$ for three independent experiments. ${ }^{*} P<0.05,{ }^{* *} P<0.01$, vs. $0 \mathrm{~h}$ (Student's $t$-test)
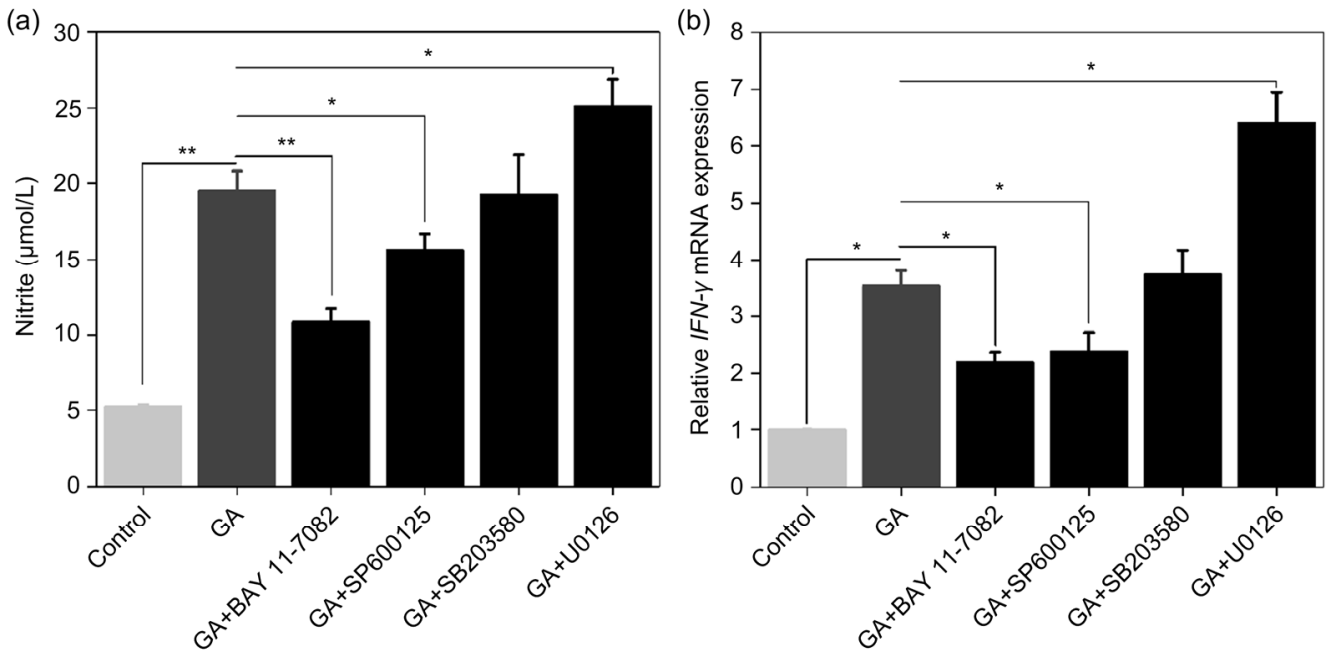

Fig. 6 Effects of glycyrrhizic acid (GA) on the signaling pathways of chicken macrophages HD11 cells were pretreated with NF-kB inhibitor (BAY 11-7082, $20 \mu \mathrm{mol} / \mathrm{L})$, JNK inhibitor (SP600125, $20 \mu \mathrm{mol} / \mathrm{L}$ ), p38 inhibitor (SB203580, $20 \mu \mathrm{mol} / \mathrm{L}$ ), or ERK1/2 inhibitor (U0126, $20 \mu \mathrm{mol} / \mathrm{L}$ ) for $30 \mathrm{~min}$ followed by the treatment with GA $(100 \mu \mathrm{g} / \mathrm{ml})$ for 48 or $6 \mathrm{~h}$. Then the production of nitrite (a) and expression of $I F N-\gamma$ (b) were measured. Results are expressed as mean $\pm \mathrm{SD}$ for three independent experiments. ${ }^{*} P<0.05,{ }^{* *} P<0.01$ (Student's $t$-test) 
mRNA expression and thereby markedly induced the productions of $\mathrm{NO}$ and $\mathrm{H}_{2} \mathrm{O}_{2}$, which led to a marked reduction of ST viability in macrophages. Similar results were obtained from an in vitro study, in which $\beta$ 1-4 mannobiose enhanced the productions of NO and $\mathrm{H}_{2} \mathrm{O}_{2}$, and resulted in decreased intracellular survival of SE in chicken MQ-NCSU cells (Ibuki et al., 2011).

IFN- $\gamma$, which is involved in the activation of macrophages and $\mathrm{T}$ lymphocytes, is another important antimicrobial molecule in host resistance against Salmonella. Macrophages primed with IFN- $\gamma$ appeared to be more sensitive to bacterial components (e.g. LPS) than untreated cells (Sweet et al., 1998; Held et al., 1999), and IFN- $\gamma$ production was upregulated in organs after ST infection (Withanage et al., 2005 ) and thereby conduced to the clearance of ST in chickens (Beal et al., 2004). In our study, GA exposure could up-regulate $I F N-\gamma, L I T A F, I L-6$, and $I L-10$ gene expression, and this may amplify the bacterial signal to macrophages and thus augment the killing of ST.

It is known that macrophage activation requires stimulation of specific transcription factors, among which MAPKs (ERK1/2, JNK, and p38 MAPK) and $\mathrm{NF}-\kappa \mathrm{B}$ are well characterized in both mammalian and avian cells in response to pathogen infection (He and Kogut, 2003; Han et al., 2009). MAPKs regulate the expression of various inflammatory cytokines (He and Kogut, 2003). NF- $\mathrm{\kappa B}$ proteins are detached from its inhibitor inhibitory $\kappa \mathrm{B}$ (IкB) after activation, and finally translocate to the nucleus and manipulate the transcription of an array of antimicrobial genes such as $i N O S$ (Han et al., 2009). We found that NF-kB and JNK pathway inhibition potently down-regulated the GA-induced NO production and $I F N-\gamma$ expression in stimulated cells, while suppression of ERK1/2 up-regulated $\mathrm{NO}$ and $I F N-\gamma$ levels. These results were supported by previous observations, in which NF- $\mathrm{KB}$ and JNK inhibitor successfully reduced $\mathrm{NO}$ and IFN- $\gamma$ secretion while ERK1/2 inhibitor markedly increased NO production in murine bone marrowderived dendritic cells (BMDCs) (Mao et al., 2015; Li et al., 2017). These findings indicated that NF- $\mathrm{kB}$ and JNK activation are required for GA-activated chicken macrophages, whereas ERK1/2 signaling may exhibit a regulatory effect to limit excessive inflammation.

In conclusion, our results indicated that GA could activate chicken macrophages and enhance phagocytic and Salmonella-killing capacity by enhancing the productions of reactive oxygen and nitrogen species and by increasing the expression of antimicrobial genes. Further in vivo studies are required to validate the efficacy of GA as a dietary intervention to reduce or eliminate Salmonella contamination in poultry production.

\section{Contributors}

Wei-fen LI, Bai-kui WANG, and Yu-long MAO conceived and designed the experiments; Bai-kui WANG, Yulong MAO, and Li GONG performed the experiments; Xin XU analyzed the data; Yi-bing WANG made the figures; Bai-kui WANG, Shou-qun JIANG, and Yu-long MAO wrote the paper.

\section{Compliance with ethics guidelines}

Bai-kui WANG, Yu-long MAO, Li GONG, Xin XU, Shou-qun JIANG, Yi-bing WANG, and Wei-fen LI declare that they have no conflict of interest.

This article does not contain any studies with human or animal subjects performed by any of the authors.

\section{References}

Barrow PA, Huggins MB, Lovell MA, 1994. Host specificity of Salmonella infection in chickens and mice is expressed in vivo primarily at the level of the reticuloendothelial system. Infect Immun, 62(10):4602-4610.

Beal RK, Powers C, Wigley P, et al., 2004. Temporal dynamics of the cellular, humoral and cytokine responses in chickens during primary and secondary infection with Salmonella enterica serovar Typhimurium. Avian Pathol, 33(1):25-33.

https://doi.org/10.1080/03079450310001636282

Bhattacharjee S, Bhattacharjee A, Majumder S, et al., 2012. Glycyrrhizic acid suppresses Cox-2-mediated antiinflammatory responses during Leishmania donovani infection. J Antimicrob Chemother, 67(8):1905-1914. https://doi.org/10.1093/jac/dks159

Bogdan C, 2001. Nitric oxide and the immune response. Nat Immunol, 2(10):907-916. https://doi.org/10.1038/ni1001-907

Braukmann M, Methner U, Berndt A, 2015. Immune reaction and survivability of Salmonella Typhimurium and Salmonella infantis after infection of primary avian macrophages. PLOS ONE, 10(3): 0122540. https://doi.org/10.1371/journal.pone. 0122540

Brown BN, Valentin JE, Stewart-Akers AM, et al., 2009. Macrophage phenotype and remodeling outcomes in response to biologic scaffolds with and without a cellular component. Biomaterials, 30(8):1482-1491. https://doi.org/10.1016/j.biomaterials.2008.11.040

Bustin SA, Benes V, Garson JA, et al., 2009. The MIQE guidelines: Minimum Information for Publication of 
Quantitative Real-Time PCR Experiments. Clin Chem, 55(4):611-622.

https://doi.org/10.1373/clinchem.2008.112797

Cinatl J, Morgenstern B, Bauer G, et al., 2003. Glycyrrhizin, an active component of liquorice roots, and replication of SARS-associated coronavirus. Lancet, 361(9374):20452046. https://doi.org/10.1016/S0140-6736(03)13615-X

Dai JH, Iwatani Y, Ishida T, et al., 2001. Glycyrrhizin enhances interleukin-12 production in peritoneal macrophages. Immunology, 103(2):235-243. https://doi.org/10.1046/j.1365-2567.2001.01224.x

Ding AH, Nathan CF, Stuehr DJ, 1988. Release of reactive nitrogen intermediates and reactive oxygen intermediates from mouse peritoneal macrophages. Comparison of activating cytokines and evidence for independent production. J Immunol, 141(7):2407-2412.

Han Y, Niu MS, An LJ, et al., 2009. Upregulation of proinflammatory cytokines and NO production in BV-activated avian macrophage-like cell line (HD11) requires MAPK and NF- $\mathrm{BB}$ pathways. Int Immunopharmacol, 9(7-8): 817-823. https://doi.org/10.1016/j.intimp.2009.03.008

Haraga A, Ohlson MB, Miller SI, 2008. Salmonellae interplay with host cells. Nat Rev Microbiol, 6(1):53-66. https://doi.org/10.1038/nrmicro1788

He HQ, Kogut MH, 2003. CpG-ODN-induced nitric oxide production is mediated through clathrin-dependent endocytosis, endosomal maturation, and activation of PKC, MEK1/2 and $\mathrm{p} 38 \mathrm{MAPK}$, and NF- $\mathrm{\kappa B}$ pathways in avian macrophage cells (HD11). Cell Signal, 15(10):911-917. https://doi.org/10.1016/S0898-6568(03)00100-1

He HQ, Genovese KJ, Swaggerty CL, et al., 2012. A comparative study on invasion, survival, modulation of oxidative burst, and nitric oxide responses of macrophages (HD11), and systemic infection in chickens by prevalent poultry Salmonella serovars. Foodborne Pathog Dis, 9(12): 1104-1110. https://doi.org/10.1089/fpd.2012.1233

Held TK, Xiao WH, Liang Y, et al., 1999. Gamma interferon augments macrophage activation by lipopolysaccharide by two distinct mechanisms, at the signal transduction level and via an autocrine mechanism involving tumor necrosis factor alpha and interleukin-1. Infect Immun, 67(1):206-212.

Honda H, Nagai Y, Matsunaga T, et al., 2012. Glycyrrhizin and isoliquiritigenin suppress the LPS sensor Toll-like receptor 4/MD-2 complex signaling in a different manner. J Leukoc Biol, 91(6):967-976. https://doi.org/10.1189/jlb.0112038

Hua H, Liang ZF, Li WW, et al., 2012. Phenotypic and functional maturation of murine dendritic cells (DCs) induced by purified Glycyrrhizin (GL). Int Immunopharmacol, 12(3):518-525.

https://doi.org/10.1016/j.intimp.2012.01.006

Ibuki M, Kovacs-Nolan J, Fukui K, et al., 2011. $\beta$ 1-4 man- nobiose enhances Salmonella-killing activity and activates innate immune responses in chicken macrophages. Vet Immunol Immunopathol, 139(2-4):289-295.

https://doi.org/10.1016/j.vetimm.2010.10.011

Li YL, Wang YY, Wu YP, et al., 2017. Echinacea pupurea extracts promote murine dendritic cell maturation by activation of JNK, p38 MAPK and NF-kB pathways. Dev Comp Immunol, 73:21-26.

https://doi.org/10.1016/j.dci.2017.03.002

Mao YL, Wang BK, Xu X, et al., 2015. Glycyrrhizic acid promotes $\mathrm{M} 1$ macrophage polarization in murine bone marrow-derived macrophages associated with the activation of JNK and NF-kB. Mediators Inflamm, 2015:372931. https://doi.org/10.1155/2015/372931

Mastroeni P, Vazquez-Torres A, Fang FC, et al., 2000. Antimicrobial actions of the NADPH phagocyte oxidase and inducible nitric oxide synthase in experimental salmonellosis. II. Effects on microbial proliferation and host survival in vivo. $J$ Exp Med, 192(2):237-248. https://doi.org/10.1084/jem.192.2.237

Matsui S, Matsumoto H, Sonoda Y, et al., 2004. Glycyrrhizin and related compounds down-regulate production of inflammatory chemokines IL-8 and eotaxin 1 in a human lung fibroblast cell line. Int Immunopharmacol, 4(13): 1633-1644. https://doi.org/10.1016/j.intimp.2004.07.023

Michaelis M, Geiler J, Naczk P, et al., 2010. Glycyrrhizin inhibits highly pathogenic H5N1 influenza A virusinduced pro-inflammatory cytokine and chemokine expression in human macrophages. Med Microbiol Immunol, 199(4):291-297. https://doi.org/10.1007/s00430-010-0155-0

Mosser DM, Edwards JP, 2008. Exploring the full spectrum of macrophage activation. Nat Rev Immunol, 8(12):958-969. https://doi.org/10.1038/nri2448

Nolan A, Weiden M, Kelly A, et al., 2008. CD40 and CD80/86 act synergistically to regulate inflammation and mortality in polymicrobial sepsis. Am J Respir Crit Care Med, 177(3):301-308. https://doi.org/10.1164/rccm.200703-515OC

Pugh ND, Balachandran P, Lata H, et al., 2005. Melanin: dietary mucosal immune modulator from Echinacea and other botanical supplements. Int Immunopharmacol, 5(4): 637-647. https://doi.org/10.1016/j.intimp.2004.12.011

Revolledo L, Ferreira CSA, Ferreira AJP, 2009. Prevention of Salmonella Typhimurium colonization and organ invasion by combination treatment in broiler chicks. Poult Sci, 88(4):734-743. https://doi.org/10.3382/ps.2008-00410

Rimaniol AC, Gras G, Clayette P, 2007. In vitro interactions between macrophages and aluminum-containing adjuvants. Vaccine, 25(37-38):6784-6792. https://doi.org/10.1016/j.vaccine.2007.06.051

Rosenberger CM, Finlay BB, 2002. Macrophages inhibit Salmonella Typhimurium replication through MEK/ERK 
kinase and phagocyte NADPH oxidase activities. $J$ Biol Chem, 277(21):18753-18762.

https://doi.org/10.1074/jbc.M110649200

Scallan E, Hoekstra RM, Mahon BE, et al., 2015. An assessment of the human health impact of seven leading foodborne pathogens in the United States using disability adjusted life years. Epidemiol Infect, 143(13):2795-2804. https://doi.org/10.1017/S0950268814003185

Setta A, Barrow PA, Kaiser P, et al., 2012. Immune dynamics following infection of avian macrophages and epithelial cells with typhoidal and non-typhoidal Salmonella enterica serovars; bacterial invasion and persistence, nitric oxide and oxygen production, differential host gene expression, NF- $\mathrm{KB}$ signalling and cell cytotoxicity. Vet Immunol Immunopathol, 146(3-4):212-224. https://doi.org/10.1016/j.vetimm.2012.03.008

Sweet MJ, Stacey KJ, Kakuda DK, et al., 1998. IFN- $\gamma$ primes macrophage responses to bacterial DNA. J Interferon Cytokine Res, 18(4):263-271. https://doi.org/10.1089/jir.1998.18.263

Tang LL, Zhang Z, Zheng JS, et al., 2005. Phenotypic and functional characteristics of dendritic cells derived from human peripheral blood monocytes. $J$ Zhejiang Univ-Sci $B, 6(12): 1176-1181$. https://doi.org/10.1631/jzus.2005.B1176

Wang LQ, He Y, Wan HF, et al., 2017. Protective mechanisms of hypaconitine and glycyrrhetinic acid compatibility in oxygen and glucose deprivation injury. $J$ Zhejiang UnivSci B (Biomed \& Biotechnol), 18(7):586-596. https://doi.org/10.1631/jzus.B1600270

Withanage GSK, Wigley P, Kaiser P, et al., 2005. Cytokine and chemokine responses associated with clearance of a primary Salmonella enterica serovar Typhimurium infection in the chicken and in protective immunity to rechallenge. Infect Immun, 73(8):5173-5182. https://doi.org/10.1128/IAI.73.8.5173-5182.2005

\section{List of electronic supplementary materials}

Fig. S1 In vitro antibacterial activity of glycyrrhizic acid against Salmonella Typhimurium

Fig. S2 Effect of glycyrrhizic acid on Salmonella Typhimurium virulence gene expression in vitro

Table S1 List of real-time PCR primers

\section{中文概要}

题 目: 甘草酸对体外鸡巨噬细胞免疫和杀菌功能的影响

目 的: 探究甘草酸能否激活体外鸡巨噬细胞并增强其免 疫和吞噬杀菌功能。

创新点: 甘草酸通过核因子 $\kappa \mathrm{B}(\mathrm{NF}-\kappa \mathrm{B})$ 和 c-Jun 氨基端 激酶 (JNK) 信号通路提高一氧化氮 (NO) 和过 氧化氢 $\left(\mathrm{H}_{2} \mathrm{O}_{2}\right)$ 产生量, 增强了其吞噬和杀菌的 功能。

方 法: 以不同浓度的甘草酸（0、12.5、25、50、100、 200、400 和 $800 \mu \mathrm{g} / \mathrm{ml}$ ) 处理鸡巨噬细胞系 HD11, 采用荧光定量聚合酶链式反应 ( $q P C R$ ) 和一氧 化氮及过氧化氢测定试剂盒评价甘草酸对鸡巨 噬细胞活化和免疫的影响, 采用流式细胞技术和 涂板计数法测定鸡巨噬细胞吞噬和杀菌能力。

结 论: 甘草酸通过 NF- $\mathrm{KB}$ 和 JNK 信号通路激活鸡巨噬 细胞, 提高免疫细胞因子等基因的表达水平和 $\mathrm{NO}$ 及 $\mathrm{H}_{2} \mathrm{O}_{2}$ 的产生量, 从而增强了鸡巨噬细胞吞 噬和清除胞内沙门氏菌的能力。

关键词: 甘草酸; 鸡巨噬细胞; 巨噬细胞活化; 鼠伤寒沙 门氏菌; 核因子 $\kappa \mathrm{B}(\mathrm{NF}-\kappa \mathrm{B})$; c-Jun氨基端激酶 (JNK) 